\title{
Integracja wyników badania aktywną termografią i techniką terahercową na potrzeby oceny defektów w materiałach kompozytowych
}

\author{
Data fusion of active termography \\ and terahetz technique inspection results \\ in composite materials defects evaluation
}

\section{Streszczenie}

W niniejszym artykule prezentowana jest technika wykrywania i oceny wad w materiałach kompozytowych, bazująca na integracji aktywnej termografii i metody terahercowej. W badaniach eksperymentalnych została wykorzystana próbka wykonana z kompozytu szklanego z szeregiem nawierceń symulujących rzeczywiste wady. W związku z faktem, iż aktywna termografia i technika terahercowa są wrażliwe na zmiany różnych parametrów fizycznych materiału, połączenie wyników uzyskanych za pomocą obydwu metod pozwoli na otrzymanie możliwie pełnej informacji o badanej próbce.

Słowa kluczowe: aktywna termografia podczerwona; technika terahercowa; fuzja danych; materiały kompozytowe

\begin{abstract}
In this paper the technique of defects evaluation in composite materials based on a combination of active thermography method and terahertz technique is presented. The composite glass fiber sample with arifitial cirindlical defects having different depths was chosen for the tests. Active Infrared thermography with halogen lamps and terahertz technique are sensitive to changes in different physical parameters of the tested material. The combination of these techniques, performed by the data fusion of obtained measurements results allows to obtain the more complete on the detected material's defect.
\end{abstract}

Keywords: active infrared thermography; terahertz technique; data fusion; composite materials

\section{Wstęp}

Materiały kompozytowe, ze względu na ich lekkość, odporność i łatwość w użytkowaniu, są coraz częściej używane w szeregu gałęzi przemysłu. Konstrukcje kompozytowe spotkać można w przemyśle lotniczym, okrętowym, czy energetycznym - jako elementy elektrowni wiatrowych. Oczywiście, struktury te często poddawane są dużym obciążeniom, co w dłuższym procesie użytkowania prowadzi do znacznego osłabienia materiału i może powodować dalekie w skutkach awarie. Dlatego wymagana jest ciągła kontrola stanu tych konstrukcji przy użyciu metod nieniszczących, co obecnie jest realizowane głównie za pomocą techniki ultradźwiękowej oraz radiografii.

W niniejszej pracy Autorzy proponują użycie dwóch metod badań nieniszczących do zbadania stanu przygotowanej próbki. Aktywna termografia podczerwona ze wzbudzeniem lampami halogenowymi może służyć zarówno do globalnej oceny materiału, jak i do oceny lokalnej (przy wykorzystaniu obiektywów typu makro lub mikro), a jej przydatność została udowodniona dla wielu rodzajów badanych materiałów. Trzeba jednakże zauważyć, że metoda ta daje słabsze wyniki w przypadku niektórych kompozytów odznaczających się niską wartością współczynnika przewodności cieplnej. Innymi parametrami fizycznymi, na których zmianę jest wrażliwa technika aktywnej termografii wzbudzana lampami halogenowymi, są gęstość materiału oraz jego pojemność cieplna. W przypadku drugiej stosowanej tutaj metody - techniki terahercowej - ważnym parametrem okazuje się być wartość współczynnika refrakcji, dlatego też metoda ta daje szczególnie dobre rezultaty w przypadku warstwowych materiałów kompozytowych. Trzeba zaznaczyć jednak, że w przypadku techniki terahercowej należy mówić o inspekcji lokalnej, jako iż badanie odbywa się punkt po punkcie.

Dr inż. Przemysław Łopato; de Barbara Szymanik, dr inż. Grzegorz Psuj- Zachodniopomorski Uniwersytet Technologiczny w Szczecinie, Wydział Elektryczny Katedra Elektrotechniki Teoretycznej i Informatyki.

Autor korespondencyjny/Corresponding author: plopato@zut.edu.pl 
W niniejszym artykule w pierwszej kolejności zostaną zaprezentowane metody eksperymentalne, następnie wyniki badania próbki kompozytowej, które zostały wykonane oddzielnie przy użyciu każdej z metod. Na koniec zostanie przedstawiona metodyka oraz wyniki procesu integracji rezultatów otrzymanych obiema metodami, przy wykorzystaniu zaawansowanych algorytmów fuzji danych.

\section{Metody eksperymentalne}

Termografia podczerwona jest jedną z najpopularniejszych technik badań nieniszczących i ma szerokie zastosowanie $[1 \div 4,16]$. Technika ta dzieli się na dwie podstawowe kategorie - termografię pasywną (TP) i aktywną (TA). TP jest używana w przypadku, gdy badany obiekt nie znajduje się w równowadze termodynamicznej i można zauważyć fluktuacje rozkładu temperatury na jego powierzchni bez użycia zewnętrznego źródła energii. Jednak w przypadku, gdy badany obiekt znajduje się w równowadze termodynamicznej, badanie pasywne nie może dać dobrych rezultatów. Stosuje się wtedy metodę termografii aktywnej, która wykorzystuje zewnętrzne źródło energii do wymuszenia przepływu ciepła w obrębie badanego materiału. Obecność różnego rodzaju wad zaburza naturalny przepływ ciepła i powoduje, że w ich okolicy powstają obserwowalne i mierzalne obszary chłodniejsze lub cieplejsze niż tło. Istnieje szereg możliwych do użycia źródeł energii: lampy halogenowe, lampy błyskowe, strumień powietrza, grzejniki radiacyjne, generatory mikrofal, źródła wibracyjne itp. W badaniach zaprezentowanych w tym artykule próbka była nagrzewana poprzez pojedynczy, długi impuls ciepła wytworzony za pomocą lamp halogenowych.

Drugą techniką wykorzystywaną w niniejszej pracy jest metoda terahercowa. Promieniowanie elektromagnetyczne w zakresie terahercowym (0.1-10 THz) umożliwia bezinwazyjne, niejonizujące i bezkontaktowe badanie dielektrycznych struktur kompozytowych. Metoda ta jest czuła na zmiany przenikalności dielektrycznej $\varepsilon$, tak więc każdy defekt wystarczająco ją zmieniający (np. pustki, rozwarstwienia, wilgoć itd.) może zostać wykryty. Najczęściej defekty wykrywane są za pomocą impulsowej spektroskopii czasowej TDS (ang. Time Domain Spectroscopy) $[5 \div 8,14,15]$. W technice tej generowane są impulsy o czasach trwania rzędu pikosekund, które następnie są skupiane za pomocą soczewek lub zwierciadeł na powierzchni badanego obiektu i odbierane po przejściu przez materiał (metoda transmisyjna) lub odbiciu się od niego (metoda odbiciowa, stosowana w niniejszej pracy). Dzięki zastosowaniu ultra krótkich impulsów możliwe jest wydajne badanie materiałów wielowarstwowych - każda granica pomiędzy poszczególnymi warstwami powoduje odbicie padającego impulsu. Analiza odpowiedzi materiału na pojedynczy impuls wzbudzający umożliwia wyznaczenie grubości warstw i określenie stanu struktury materiału.

\section{Próbka kompozytowa}

Badana próbka, o wymiarach $85 \times 50 \times 5 \mathrm{~mm}$, została wykonana ze wzmocnionego kompozytu szklanego [4]. Aby przetestować możliwość wykrycia różnego rodzaju wad za pomocą obu wykorzystywanych tutaj metod nieniszczących, wykonano szereg sztucznych wad w postaci nawierceń bocznych oraz otworów o różnych średnicach i głębokościach. Rysunek 1 przedstawia zdjęcie próbki oraz jej schematyczny rysunek. Próbka zawiera dwie główne grupy wad: 12 otworów, w czterech rzędach po trzy, o różnych średnicach (od 1 do $4 \mathrm{~mm}$ ) i głębokościach (od 2 do $4 \mathrm{~mm}$ ) oraz 21 nawierceń bocznych, każde o średnicy $1 \mathrm{~mm}$ zlokalizowanych na różnych głębokościach. Należy podkreślić, że wady mają małe rozmiary oraz są zlokalizowane blisko siebie (w szczególności dotyczy to nawierceń bocznych, gdzie minimalna odległość między wadami wynosiła $1 \mathrm{~mm}$ ), co pozwoli określić rozdzielczość obu metod. Próbka została pokryta czarną farbą o emisyjności bliskiej jedności, co jest wymagane w przypadku stosowania termografii aktywnej. Ponadto aluminiowa taśma została naklejona na pewne obszary próbki. Taśma ta będzie widoczna w wynikach otrzymanych w obu metodach, co umożliwi rejestrację wyników do jednej przestrzeni.

a)

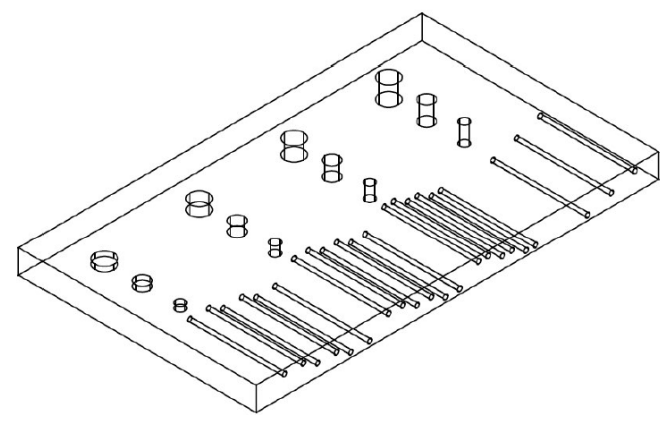

b)

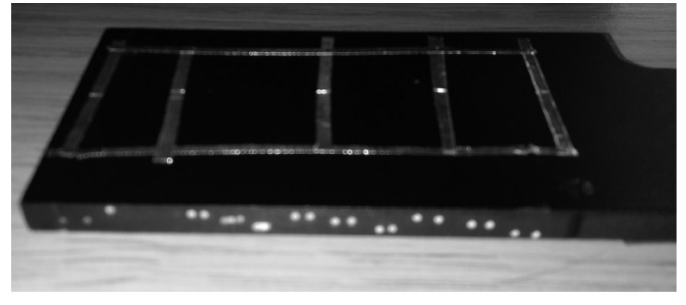

c)

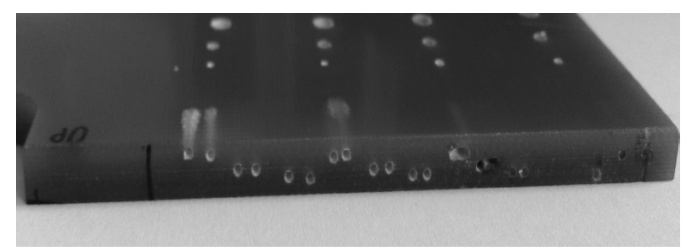

Rys. 1. Badana próbka wykonana z kompozytu szklanego: a) schemat próbki wraz $z$ wadami, b) fotografia próbki z widocznym markerem aluminiowym, c) fotografia próbki z widocznymi wadami

Fig. 1. Evaluated glass-fiber reinforced composite sample: a) geometry of the sample, b) photo of painted sample with markers, c) photo of raw sample with artificial defects

\section{Układy eksperymentalne}

Badania metodą aktywnej termografii zostały wykonane przy wykorzystaniu lampy halogenowej (o mocy do 2000 W) i kamery termowizyjnej FLIR A325. Zdjęcie wykorzystywanego układu laboratoryjnego przedstawiono na rysunku 2a. Lampę umieszczono za próbką, a obserwacja przy użyciu kamery termowizyjnej była realizowana z drugiej strony. W tym układzie wady powinny być widoczne jako cieplejsze miejsca, ze względu na szybszy wzrost temperatury w miejscach, gdzie materiału jest mniej. Jak wspomniano wcześniej, szklane materiały kompozytowe z reguły charakteryzują się niską wartością współczynnika przewodzenia ciepła, dlatego czas grzania był relatywnie długi. Grzano impulsem, którego czas trwania został ustalony na $60 \mathrm{~s}$. Po tym czasie, grzanie zostało wyłączone, a próbka była obserwowana przez dodatkowe $300 \mathrm{~s}$ podczas naturalnego ochładzania się w procesie konwekcyjnego przewodzenia ciepła. Rejestracja obrazów odbywała się z częstotliwością jednego termogramu na sekundę, zarówno podczas grzania, jak i okresu chłodzenia, co dało łącznie sekwencję składającą się z 360 zarejestrowanych obrazów gotowych do dalszej obróbki. 
a)

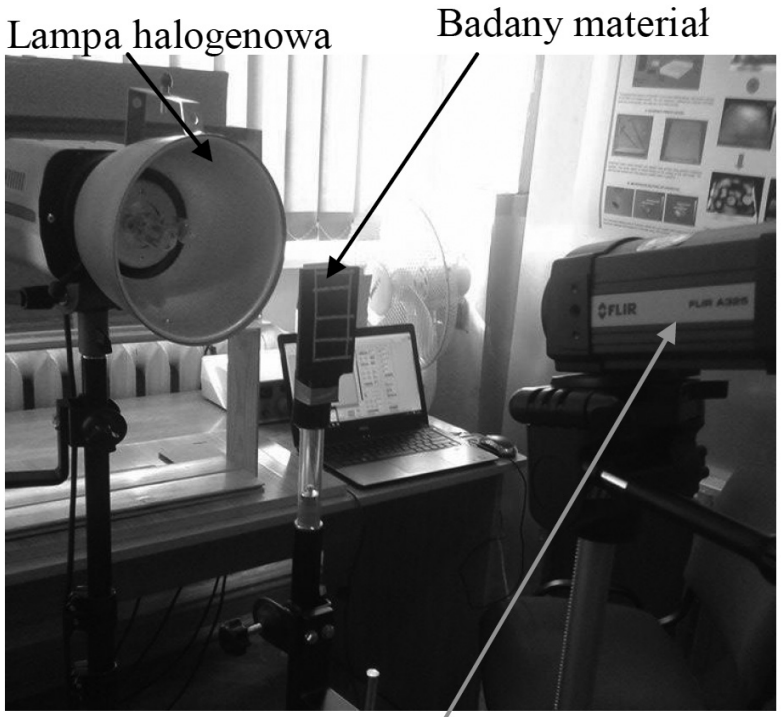

kamera termowizyjna

b)

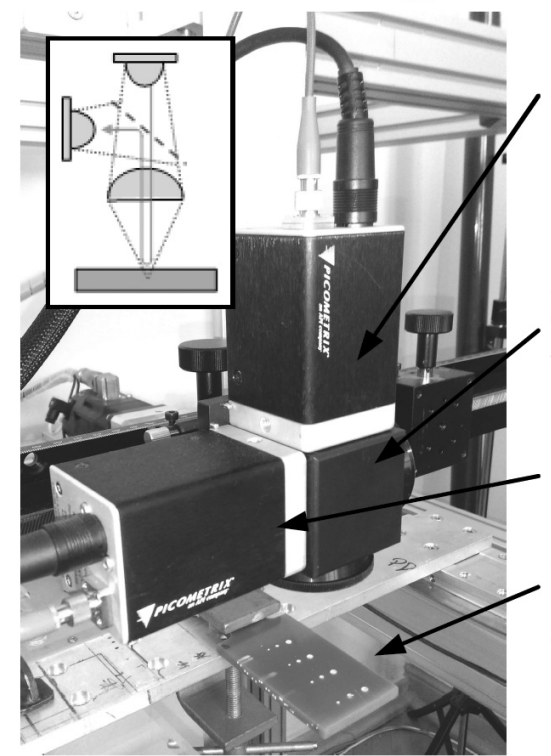

Rys. 2. Fotogratıe układów eksperymentalnych: a) system do termowizji aktywnej, b) system terahercowy

Fig. 2. Photos of measuring setups: a) IRT system, b) terahertz inspection system

Inspekcja terahercowa została przeprowadzona z wykorzystaniem systemu bazującego na impulsowym spektroskopie terahercowym TRay4000 firmy Picometrix. Głowica pomiarowa była przesuwana nad powierzchnią materiału badanego za pomocą dwuwymiarowego, kartezjańskiego układu pozycjonującego. Dla każdego punktu pomiarowego zapisywano sygnał czasowy s(t). Podobnie, jak w metodzie ultradźwiękowej, informacja czasowa (opóźnienie) jest powiązana z głębokością w materiale. Impulsy pikosekundowe generowane są przez antenę fotoprzewodzącą PCA (ang. Photo-Conductive Antenna) znajdującą się w głowicy nadawczej, skupiane przez soczewki o ogniskowej 3 " wykonane z HDPE i ostatecznie, po interakcji z obiektem badanym, odbierane przez antenę PCA w głowicy odbiorczej. W celu uzyskania odbicia fali pod kątem prostym do powierzchni badanej zastosowano rozdzielacz wiązki terahercowej, jak przedstawiono na rysunku $2 \mathrm{~b}$.

\section{Wyniki eksperymentów}

\section{Wyniki otrzymane metodą termografii aktywnej TA}

W związku z małymi rozmiarami otworów oraz naturalnie niejednorodnym grzaniem, same termogramy nie dają możliwie pełnej informacji na temat położenia wad, dlatego otrzymana sekwencja termogramów została poddana odpowiedniej obróbce. Występująca w tym przypadku niejednorodność grzania może być usunięta za pomocą operacji bazującej na filtracji medianowej z dużą maską. Obraz wyjściowy jest najpierw poddawany filtracji medianowej, gdzie maska jest większa niż przybliżony rozmiar wad. W ten sposób dostaje się uśredniony obraz tła, który może być odjęty od termogramu pierwotnego.

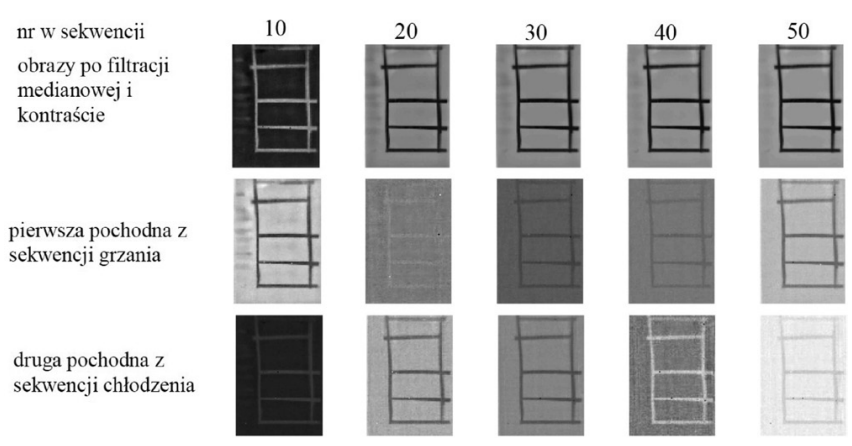

Rys. 3. Przykładowe wyniki zastosowania wybranych technik przetwarzania obrazów dla otrzymanych termogramów.

Fig. 3. Chosen results of image processing of obtained thermograms

Zastosowano także operację kontrastu zdefiniowaną następująco:

$$
O_{T}(i, j, t)=\frac{I_{T d}(i, j, t)-I_{T d}(i, j, t=0)}{I_{a s a}(t)-I_{a s a}(t=0)}
$$

Gdzie: $\mathrm{O}_{\mathrm{T}}(\mathrm{i}, \mathrm{j}, \mathrm{t})$ - wartość otrzymywana po operacji kontrastu dla każdego piksela obrazu, dla wszystkich obrazów w sekwencji, $I_{T d}(i, j, t)$ - wartość wejściowa dla każdego piksela obrazu z obszaru zdefiniowanego jako możliwa lokalizacja wad, lasa $(\mathrm{t})$ - wartość wejściowa dla każdego piksela obrazu uśredniona z obszaru zdefiniowanego jako pozbawiony wad, $\mathrm{t}=0$ oznacza pierwszy obraz $\mathrm{w}$ sekwencji.

Ponadto, mając do dyspozycji sekwencje obrazów, możemy potraktować każdy piksel obrazu jako funkcję temperatury w czasie. Dla takich funkcji obliczona została pierwsza i druga pochodna (oddzielnie dla grzania i chłodzenia). Sygnały te poddano procedurze dyskretnej transformaty Fourierowskiej, co umożliwiło otrzymanie sekwencji obrazów fazowych oraz amplitudowych. Wybrane wyniki przedstawiono na rysunku 3, a obrazy, na których wady były widoczne najlepiej, wykorzystano później w procedurze fuzji danych.

\section{Wyniki otrzymane metodą terahercową}

Przykładowe wyniki uzyskane za pomocą inspekcji terahercowej przedstawiono na rysunku 4. Dla każdej pozycji $(x, y)$ rejestrowano sygnał czasowy $s(t)$. W celu uproszczenia procesu dalszego przetwarzania informacji, sygnał ten sparametryzowano. Zmiany sygnału wywołane obecnością defektów mogą być trudne do wykrycia ze względu na fakt, iż występują na skomplikowanym tle (odpowiedź czasowa zawiera zbiór impulsów powstających w wyniku odbić od wielu warstw występujących w materiałach kompozytowych). W związku z tym zestaw cech, który zostanie wyznaczony, powinien być bardzo starannie wybrany.

W celu wyznaczenia zestawu cech sygnał czasowy podzielony został na cztery części (rys. 4.). Okna czasowe $D_{1}$ i $D_{4}$ odpowiadają przedniej i tylnej powierzchni materiału badanego, natomiast $D_{2}$ i $D_{3}$ wewnętrznej części materiału. Dla każdego okna czasowego zdefiniowano następujący zbiór cech: 
a)

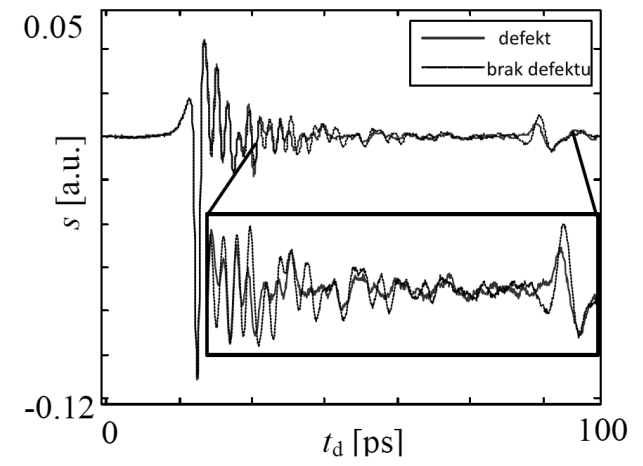

b)

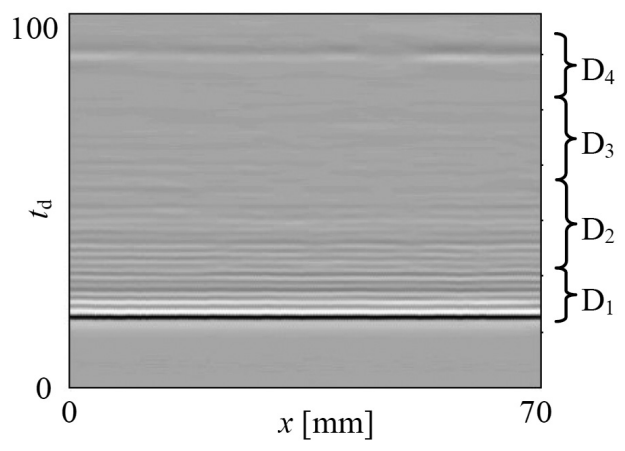

Rys. 4. Przykładowe wyniki inspekcji terahercowej: a) A-scan, b) B-scan

Fig. 4. Exemplary signals obtained using $\mathrm{THz}$ inspection: a) A-scan, b) B-scan

$$
\begin{array}{cc}
\xi_{D n, 1}=\max \left[s_{D n}(t)\right] & \xi_{D n, 4}=\int_{t_{1}} \mid s_{D n}(t) d t \\
\xi_{D n, 2}=\min \left[s_{D n}(t)\right] & \xi_{D n, 5}=\operatorname{var}\left[s_{D n}(t)\right] \\
\xi_{D n, 3}=\max \left[s_{D n}(t)\right]-\min \left[s_{D n}(t)\right] & \xi_{D n, 6}=\int_{f_{1}}^{f_{2}} \mid S_{D n}(f) d f
\end{array}
$$
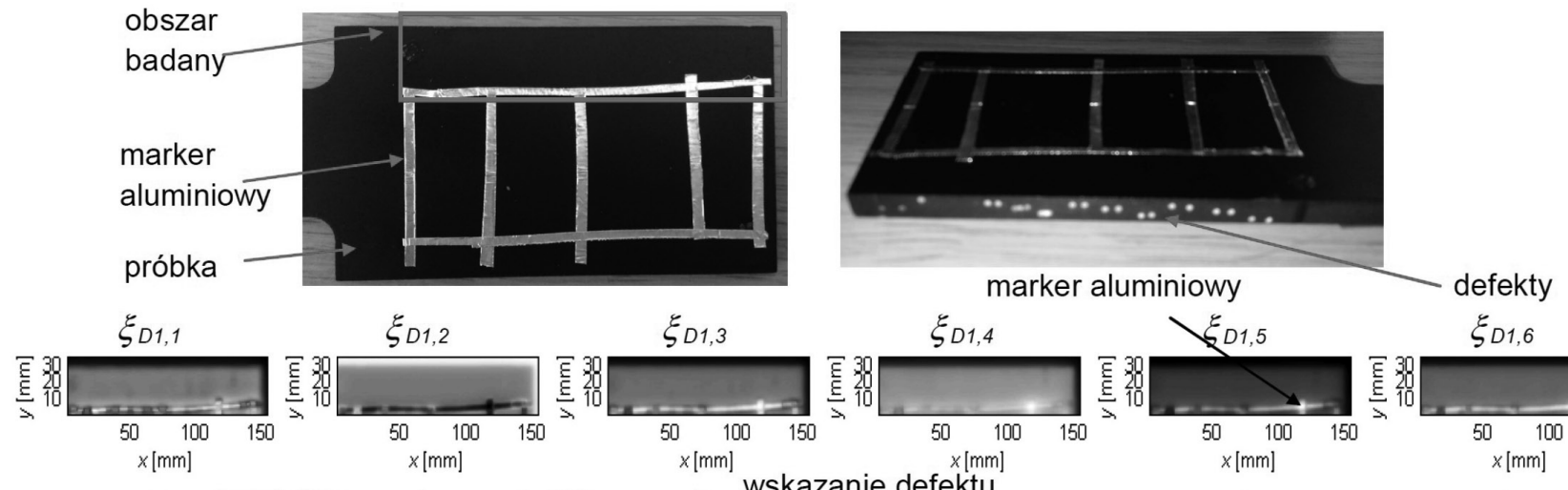

\section{Fuzja danych}

Żaden z obliczonych rozkładów powierzchniowych parametrów nie umożliwia uzyskania kompletnej informacji o strukturze badanego materiału. Z drugiej strony, nawet w przypadku pojedynczej metody badania różne parametry mogą dostarczyć niepowtarzalnych danych o bieżącym stanie struktury materiału. Przykładowo, odpowiedź w czasie
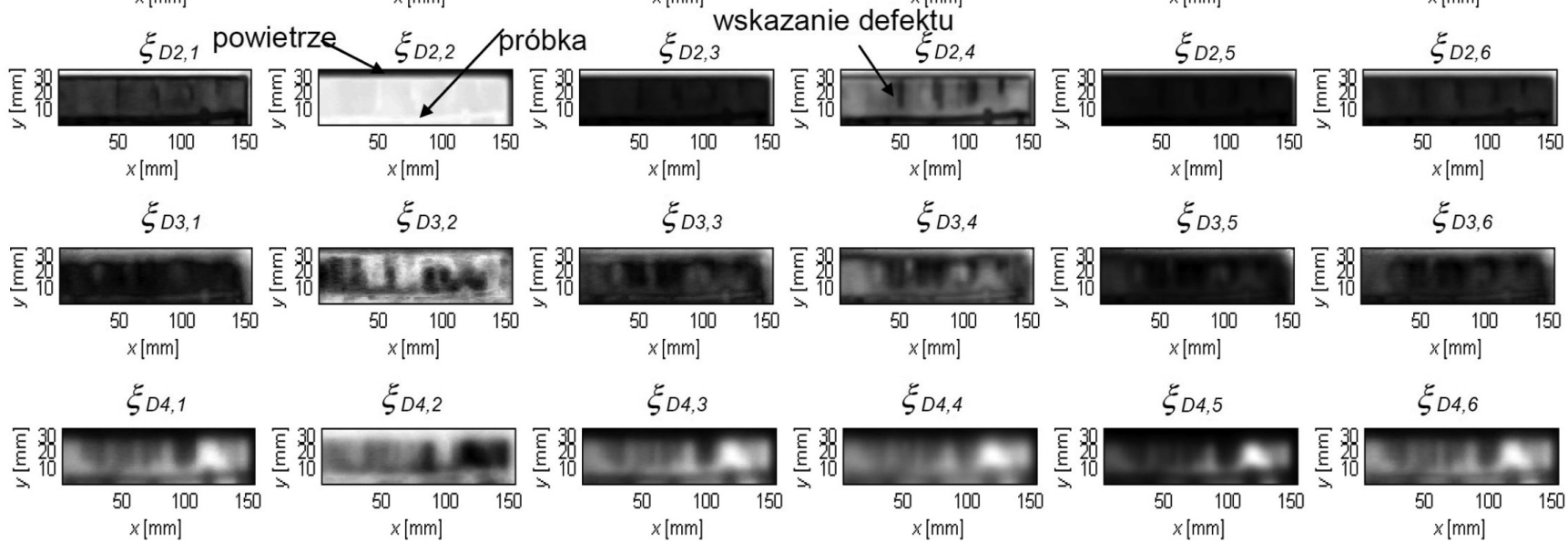

Rys. 5. Przykładowe rozkłady zaproponowanych parametrów dla defektów ukrytych (wewnętrznych)

Fig. 5. Exemplary 2D distributions of proposed parameters in case of interior defects 


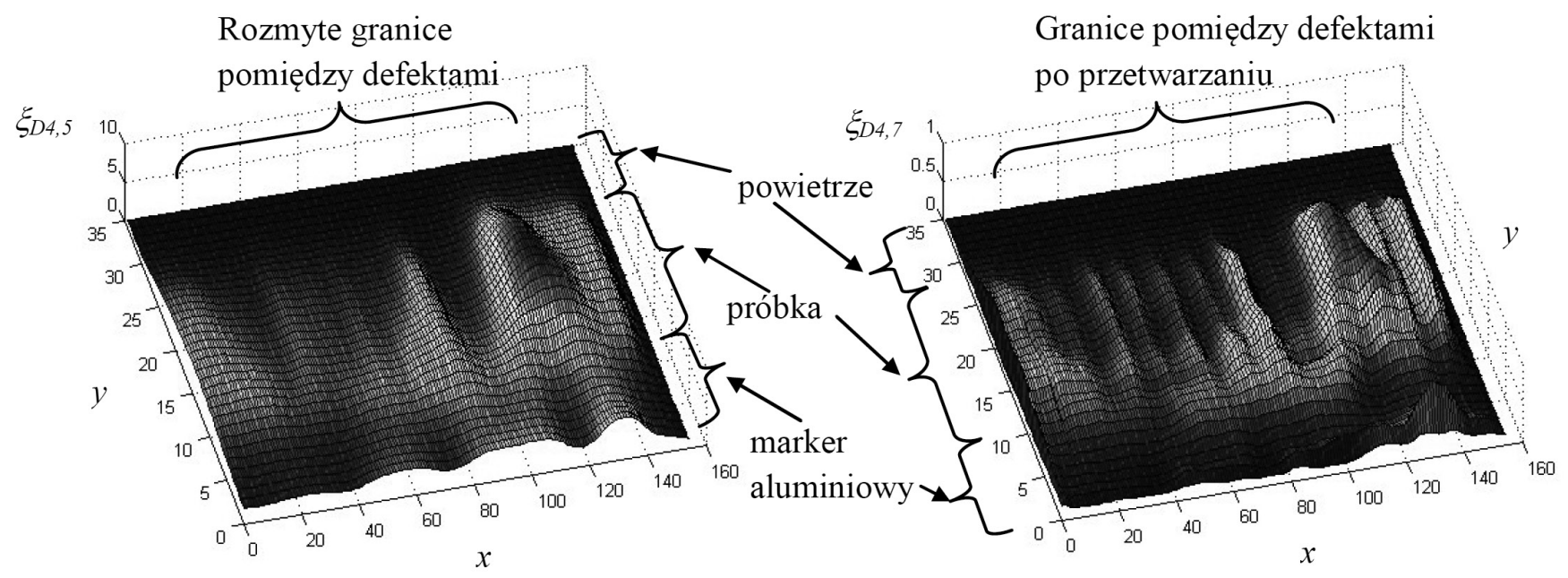

Rys. 6. Rezultaty zastosowania procedury ślepej dekonwolucji: dane nieprzetworzone (lewa strona) i dane przetworzone (prawa strona) Fig. 6. Results of utilization of blind deconvolution procedure: raw data (left side), processed data (right side)

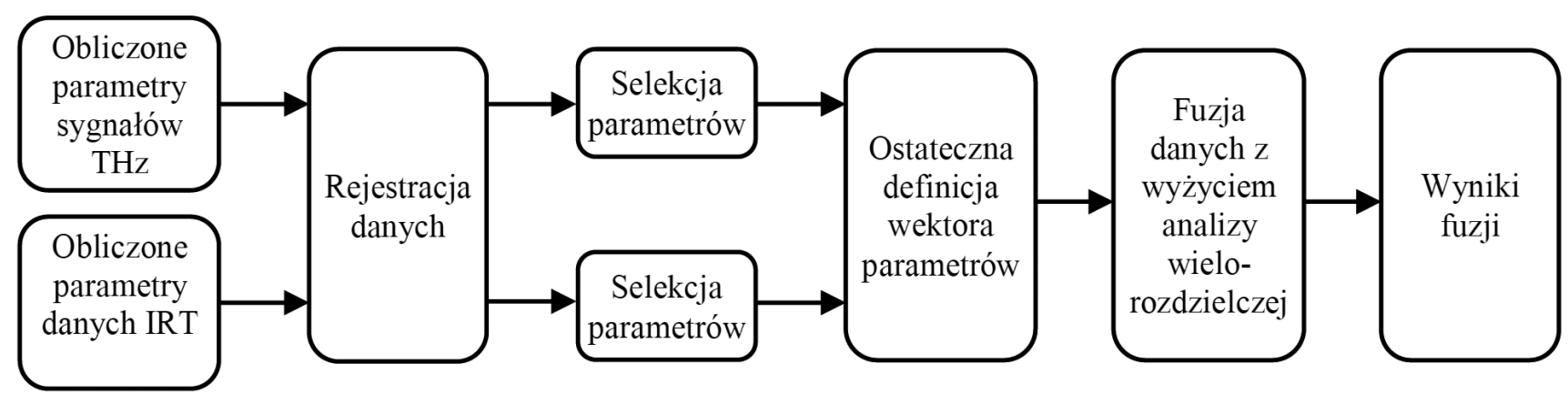

Rys. 7. Schemat zastosowanej procedury wieloparametrycznej fuzji danych

Fig. 7. The stage diagram of the applied multiparameters data fusion procedure

umożliwia monitorowanie stanu w różnych warstwach lub na różnej głębokości. Dlatego, w celu przeprowadzenia w pełni procesu nieniszczącego obrazowania stanu struktury dokonano fuzji danych z wielu parametrów wyekstrahowanych z wyników obu metod testowania. Wiele źródeł umożliwia uzyskanie systemu oceny bardziej powtarzalnego i jednocześnie odpornego na zakłócenia. W efekcie możliwe jest osiągnięcie większej precyzji w procesie oceny

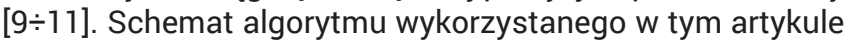
przedstawiono na rysunku 7.

W pierwszej kolejności dokonano rejestracji przestrzennej rozkładów wszystkich obliczonych parametrów wyników pomiarowych obu metod. W celu zwiększenia efektywności procedur rejestracji przed wykonaniem pomiarów na próbki naniesiono metalowe znaczniki, które są widoczne na obrazach obu metod. Linie krawędzi znaczników wykorzystano następnie do oznaczenia par punktów kontrolnych w przestrzeniach wynikowych każdej z metod. Jako obrazu odniesienia użyto wysokiej rozdzielczości zdjęcia badanej próbki. Do transformacji rozkładów parametrów do wspólnej przestrzeni wynikowej użyto standardowych modeli transformacji geometrycznych. Zależności przestrzenne występujące pomiędzy odpowiadającymi sobie parami punktów kontrolnych umożliwiały określenie wartości współczynników zastosowanych modeli transformacji [11]. Przykładowy wynik rejestracji przestrzennej danych przedstawiono na rysunku 8.

Następnie, po przeprowadzeniu procesu rejestracji zmierzony obszar próbki pomiarowej podzielano na pięć podobszarów reprezentujących różną grupę defektów $\left(\mathrm{GD}_{1}-\mathrm{GD}_{5}\right)$.

W kolejnym etapie rozkłady przestrzenne cech sygnałowych uzyskane dla każdej pojedynczej metody zostały

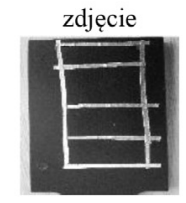

zdjęcie

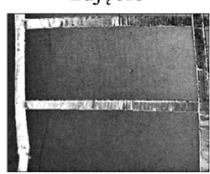

Rys. 8. Wyniki rejestracji danych: a) rozkłady parametrów danych uzyskanych obiema metodami i widok obrazu odniesienia, b) wynik po transformacji danych do wspólnej przestrzeni wynikowej

Fig. 8. Data registration results: a) input signals parameters distributions and a photo of the sample, b) transformed photo and inspection results into common representation resulting data space

przeanalizowane i poddane wstępnej selekcji. Podczas procesu preselekcji kierowano się dwoma kryteriami: minimalizacja liczby parametrów niosących podobną informację oraz zachowanie możliwości obserwacji różnych aspektów oceny stanu struktury. Ostatecznie zdefiniowany wektor cech $\mathrm{F}$ zawiera wybrany zestaw dziesięciu parametrów reprezentujących rezultaty otrzymane obiema metodami. Następnie otrzymany wektor F użyto do realizacji algorytmu fuzji danych. Przykładowe rozkłady cech składowych wektora F uzyskane dla defektów z grupy $\mathrm{GD}_{1}$ przedstawiono na rysunku 9 . W celu połączenia zawartości informacji z różnych cech oraz zmniejszenia wymiaru bazy danych dla każdego obszaru GD, zastosowano procedury przetwarzania F. Aby zmniejszyć liczbę cech w wekto- 


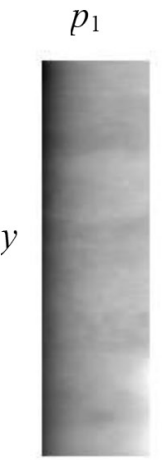

$x$

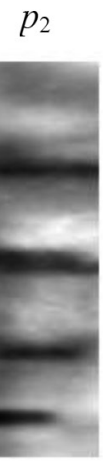

$x$

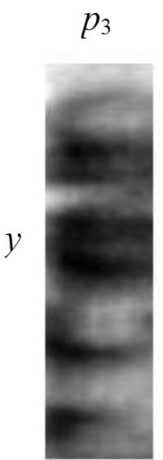

$x$

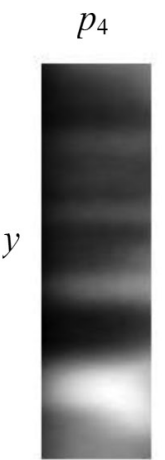

$x$

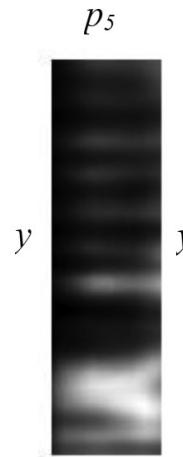

$x$

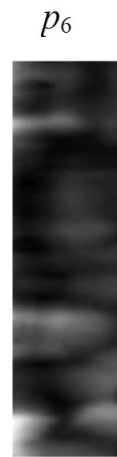

$x$

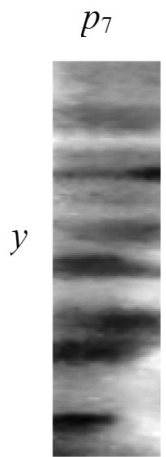

$x$

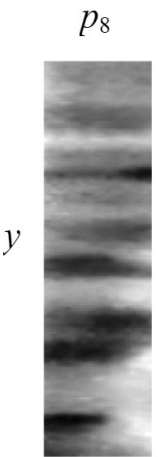

$x$

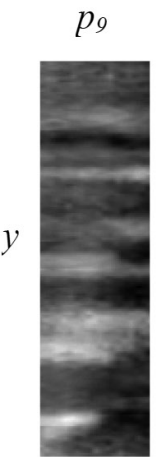

$x$

Rys. 9. Rozkład cech składowych wektora $\mathrm{F}$ dla obszaru $\mathrm{GD}_{1}$ : reprezentujących parametry obliczone na podstawie wyników metody THz $\left(p_{1}-p_{5}\right)$ i IR $\left(p_{6}-p_{10}\right)$ : $p_{1}-p_{4}$ to $\xi_{D n, 6}$ dla okien czasowych $D_{1}-D_{4}, p_{5}$ to $\xi_{D 4,7}, p_{6}-p_{8}$ to kolejno rozkład amplitudy, konstrastu termicznego i danych po filtracji medianowej w drugim kroku czasowym fazy grzania, $p_{9} i p_{10}$ to rozkład pochodnej temperatury na początku fazy odpowiednio chłodzenia i grzania

Fig. 9. Distributions of selected features representing inspection results $T H z\left(p_{1}-p_{5}\right)$ and IR $\left(p_{6}-p_{10}\right)$ inspection results: $p_{1}-p_{4}$ corespond to $\xi_{\mathrm{Dn}, 6}$ for successive time gates $D_{1}-D_{4}, p_{5}$ represents $\xi_{\mathrm{D} 4,7}, \mathrm{p}_{6}-\mathrm{p}_{8}$ represents amplitude, thermal contrast and data after median filtering distributions in the second time step of the heating stage, $p_{9}$ and $p_{10}$ represents derivative of the temperature at the beginning of the cooling stage and heating stage respectively

rze i uzyskać zbliżony do pierwotnego poziom zmienności cech w bazie, zastosowano analizę głównych składowych [12]. W konsekwencji uzyskano nowy wektor $\mathrm{F}_{\mathrm{PCA}}$ zawierający cechy zwane składowymi głównymi pc. Zmienne pc są kombinacją liniową pierwotnych cech i są posortowane wg narastającego poziomu wariancji składowych. Ostatecznie do dalszej analizy wykorzystano dwie składowe decydujące $w$ największym stopniu o zmienności w nowym wektorze.

W kolejnym etapie, w celu uzyskania ostatecznych wyników fuzji danych, przeprowadzono analizę wielorozdzielczą MRA (Multi-Resolution Analysis) [10]. W tym artykule do realizacji MRA użyto dekompozycję falkową WT z zastosowaniem falki Daubechies [13].

WT jest jednym z najbardziej skutecznych sposobów dekompozycji pozwalających na uzyskanie dobrej rozdzielczości zarówno w dziedzinie czasu jak i częstotliwości. Wyniki fuzji danych wykonanej na podstawie MRA przedstawiono na rysunku 10 . Ideą fuzji wielu danych do wspólnej reprezentacji w postaci pojedynczego obrazu jest uzyskanie uzupełniających się danych w prostszej, łatwiejszej do analizy formie. Zastosowanie fuzji danych z użyciem analizy MRA pozwala zachować informacje o przestrzennej charakterystyce zarówno wysokojak i niskoczęstotliwościowej w jednej wspólnej prezentacji. Dlatego w tym przypadku obrazowanie stanu struktury kompozytu może umożliwić osiągnięcie wyższego poziomu pewności w procesie podejmowania decyzji. Zaletę procedury integracji można zauważyć w przypadku oceny obszaru $\mathrm{GD}_{1}$. Wady te zostały wywiercone wzdłuż i pomiędzy kolejnymi warstwami włókien. W rezultacie $w$ trakcie wykonywania otworów powstały dodatkowe rozwarstwienia i degradacje w ich okolicy. Pojedyncze metody umożliwiają wskazanie wywierconych defektów (rys. 9), jednakże wpływ otrzymanych rozwarstwień na mierzone sygnały nie jest już tak widoczny. Wspomniany wpływ uszkodzeń w okolicach otworów na otrzymane parametry można zaobserwować w wynikach fuzji danych. Otwory są wskazane przez białe pasma o dużej intensywności koloru (rys. 10), podczas gdy delaminacje są reprezentowane przez mniejszą wartość uzyskanej intensywności koloru.

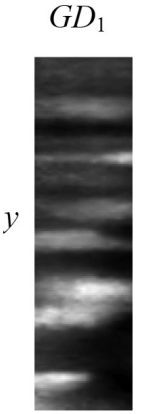

$x$
$G D_{2}$

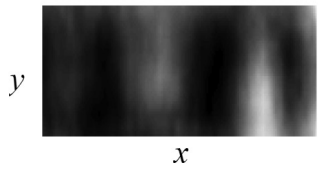

$G D_{3}$

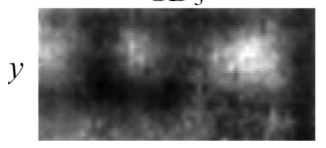

$x$
$G D_{4}$

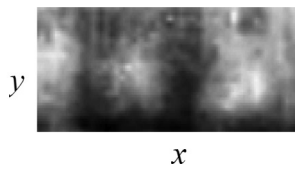

$G D_{5}$

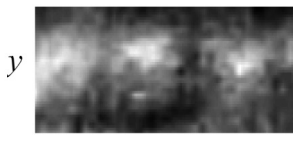

$x$
Rys. 10. Wynik fuzji danych na podstawie inspekcji obszarów poszczególnych grup defektów

Fig. 10. Results of data fusion algorithm obtained for results of inspections carried out for different gropus of defects

\section{Podsumowanie}

Ocena materiałów kompozytowych w ujęciu dzisiejszych technik badawczych stanowi trudne i skomplikowane zadanie. Wielowarstwowa struktura materiału stwarza wiele problemów w uzyskaniu rzeczywistego obrazu, a następnie poprawnej identyfikacji jego stanu. Nie ulega wątpliwości, że w tym celu obecnie używane metody inspekcji należy dalej rozwijać. Dlatego też zasadne jest rozwijanie systemów wieloźródłowych, integrujących metody umożliwiające obserwację na bazie odmiennych zjawisk fizycznych i czułych na zmianę różnych właściwości materiału. W konsekwencji systemy takie dostarczają różnych, komplementarnych informacji, które z powodzeniem mogą być połączone 
z wykorzystaniem algorytmów fuzji danych w celu zwiększenie skuteczności poprawnej identyfikacji stanu badanego materiału. W artykule tym zastosowano dwie metody badań nieniszczących do oceny próbek kompozytowych zawierających liczne defekty o niewielkich wymiarach.

W przypadku techniki TA, z uwagi na stosunkowo niską wartości przewodności cieplnej, wady tego typu są bardzo trudne do wykrycia. Uzyskane wyniki za pomocą aktywnej termografii porównano z wynikami uzyskanymi techniką terahercową. Druga z użytych metod wykazuje natomiast wrażliwość na zmiany współczynnika załamania fali. Stąd też potencjalnie stanowi bardzo przydatne narzędzie w ocenie materiałów warstwowych. Po przeprowadzeniu analizy i parametryzacji otrzymanych danych pomiarowych obu metod, a następnie zrealizowaniu procesu rejestracji przestrzennej, ostatecznie zostały połączone przy użyciu algorytmu fuzji danych z zastosowaniem analizy wielorodzielczej MRA. Wyniki fuzji danych są interesujące szczególnie w przypadku otworów bocznych, gdzie połączenie wyników obu metod umożliwiło otrzymanie informacji o lokalizacji wad, a także wskazanie obszarów powstałych rozwarstwień.

\section{Autorzy pragną podziękować prof. Ryszardowi Sikorze i prof. Tomaszowi Chademu z Katedry Elektrotechniki Teoretycznej i Informatyki ZUT w Szczecinie za wsparcie, owocne dyskusje naukowe i uwagi dotyczące tematyki pracy.}

\section{Literatura}

[1] Kapadia, Non Destructive Testing of Composite Materials, TWI Ltd.

[2] Maladegue $X$.: Theory and practice of infrared technology for nondestructive testing. JohnWiley and Sons, 2001.

[3] D. Balageas, X. Maldague, D. Burleigh V.P. Vavilov, B.Oswald-Tranta, J.-M. Roche, C. Pradere, G.M. Carlomagno: Thermal (IR) and Other NDT Techniques for Improved Material Inspection, J Nondestruct Eval (2016) 35:18.

[4] R. Sikora, T. Chady, B. Szymanik: Infrared Thermographic Testing of Composite Materials with Adhesive Joints, in proceedings of 18th WCNDT, 16-20 April 2012, Durban, South Africa.

[5] Mittelman D. M., Gupta M., Neelamani R., Baraniuk R. G., Rudd J. V., Koch M.: Recent advances in terahertz imaging, Applied Physics, Lasers and Optics, B 68 (1999), pp. 1085-1094.

[6] Lopato P., Chady T.: Terahertz detection and identification of defects in layered polymer composites and composite coatings, Nondestructive Testing and Evaluation, vol. 28, iss. 1, 2013.

[7] Palka N., Miedzińska D.: Detailed non-destructive evaluation of UHMWPE composites in the terahertz range, Optical and Quantum Electronics, 46, 2014, pp. 515-525.

[8] Mittelman D.: Sensing with terahertz radiation, Springer, Berlin, 2010.

[9] C. Kohl, M. Krause, C. Maierhofer and J. Wöstmann, 2D- and 3Dvisualisation of NDT-data using data fusion technique, Materials and Structures, 38, 2005, pp. 817-826.
[10] Z. Liu et al.: Survey: State of the Art in NDE Data Fusion Techniques, IEEE Transaction on Instrumentations and Measurements, vol. 56, no.6, 2007, pp. 2435-2436.

[11] P. Lopato, G. Psuj, B. Szymanik: Nondestructive Inspection of Thin Basalt Fiber Reinforced Composites Using Combined Terahertz Imaging and Infrared Thermography, Advances in Materials Science and Engineering, vol. 2016, Article ID 1249625, 2016. doi:10.1155/2016/1249625.

[12] C. Wang et al.: Principal component analysis based three-dimensional operational modal anlysis, International Journal of Applied Electromagnetics and Mechanics 45 (2014), pp. 137-144.

[13] J. T. Białasiewicz: Falki i aproksymacje, WNT, Warszawa 2000, ISBN 83204-2557-3.

[14] Dragan K., Kornas Ł.: Pałka N.: Problematyka diagnozowania kompozytowych konstrukcji lotniczych, Vol 83, No 13 (2011), Przegląd Spawalnictwa.

[15] Łopato P., Chady T.: Badania nieniszczące materiałów kompozytowych metodą terahercową, Vol 85, No 12 (2013): Przegląd Spawalnictwa.

[16] Jamrozik W., Fidali M., Bzymek A., Timofiejczuk A.: Zastosowanie fuzji obrazów wizyjnych i termowizyjnych do monitorowania i diagnozowania procesu spawania, Vol 83, No 1 (2011): Przegląd Spawalnictwa. 